\title{
Influence of Reproductive Season upon Plasma Biochemistry Values in Green Iguanas
}

\author{
Z. KNOTKOVÁ ${ }^{1}$, S. PEJŘILOVÁ ${ }^{2}$, Š. TRNKOVÁ ${ }^{1}$, O. MATOUŠKOVÁ ${ }^{3}$, \\ Z. KNOTEK ${ }^{1}$ \\ ${ }^{1}$ Avian and Exotic Animal Clinic, ${ }^{2}$ Clinic of Dog and Cat Diseases, \\ University of Veterinary and Pharmaceutical Sciences Brno, \\ ${ }^{3}$ Veterinary Research Institute Brno, Czech Republic
}

Received April 7, 2005

Accepted November 10, 2005

\begin{abstract}
Knotková Z., S. Pejřilová, Š. Trnková, O. Matoušková, Z. Knotek: Influence of Reproductive Season upon Plasma Biochemistry Values in Green Iguanas. Acta Vet Brno 2005, 74: 515-520.

The trial involved eleven 10-month-old green iguanas (Iguana iguana rhinolopha, 5 males/6 females) from a single clutch of captive breeding program. Lizards were housed in an experimental room and maintained in terraria $(75 \mathrm{~cm} \times 85 \mathrm{~cm} \times 85 \mathrm{~cm})$, with a constant light/temperature/air humidity regime $\left(12 \mathrm{~h} / 12 \mathrm{~h}, 24-35{ }^{\circ} \mathrm{C}, 60-80 \%\right)$. The body condition and health status of the iguanas was monitored at regular intervals. At the age of 34 months three females laid eggs spontaneously whereas the other three females suffering from pre-ovulatory follicle stasis (POFS) were ovariectomized (OVE) at the end of 35 months. Within the period of the reproductive activity (February - March, November-January) plasma concentrations of calcium, cholesterol and triglycerides were significantly higher $(p<0.05)$ in females than in males. Significantly higher concentrations of calcium and triglycerides were found in plasma samples of POFS females than in healthy females after oviposition. Plasma concentrations of calcium, phosphorus, cholesterol and triglycerides were significantly higher in intact females than in OVE females. The mechanism of hormonal control for seasonal changes of calcium, cholesterol and triglyceride concentrations in blood of female green iguana remains to be examined in the future.
\end{abstract}

Reptiles, calcium, cholesterol, triglycerides, vitellogenesis, follicular stasis

Plasma biochemistry in green iguanas has been a subject of interest for a number of authors (Dessauer 1970; Anderson 1992; Barten 1993; Divers et al. 1996; Wagner and Wetzel 1999; Bruder 1998; Harr et al. 2001). Results of previous studies show a significant degree of variation due to different animal selection, methods and technical differences in blood sample treatment (Campbell 1996; Köhler 1996; Redrobe and MacDonald 1999; Kubalek 2000; Harr et al. 2001; Walton 2001; Barten 2002; Knotek et al. 2002; Ja cobson 2003). Most trials so far consisted in analysing blood from one-off sample-takings. The goal of our trial therefore was performing a long-term study on blood-related animals kept under identical conditions.

\section{Materials and Methods}

\section{Animals}

A group of eleven 10 months-old green iguanas (Iguana iguana rhinolopha, 5 males/ 6 females) from a single clutch of captive breeding program was included in this trial. Lizards were housed in an experimental room and maintained in terraria $(75 \mathrm{~cm} \times 85 \mathrm{~cm} \times 85 \mathrm{~cm})$, with a specific light regime $(12 \mathrm{~h} / 12 \mathrm{~h}, 100 \mathrm{~W}$ bulb + UV lamp Repti-Glo, Hagen); iguanas housed in groups (two females and one male), the temperature ranged between 24 and $35^{\circ} \mathrm{C}$ and air humidity between 60 and $80 \%$. The iguanas were fed every day. The diet consisted of common dandelion leaves, carrots, tomatoes, fruits, lettuce, Chinese cabbage and cottage cheese mixed with calcium powder and pelleted commercial chow.

Control of pregnancy, ovariectomy

The body condition and health status of the iguanas was monitored at regular intervals. The coelomic cavity was controlled manually with gently palpation of the body wall. At the age of 34 months three females laid fertile and

Address for correspondence:

MVDr. Zora Knotková, CSc.

Avian and Exotic Animal Clinic

University of Veterinary and Pharmaceutical Sciences Brno

Palackého 1-3, 61242 Brno, Czech Republic
Phone: +420541562381

Fax: +420 541562381

E-mail:knotkovaz@vfu.cz

http://www.vfu.cz/acta-vet/actavet.htm 

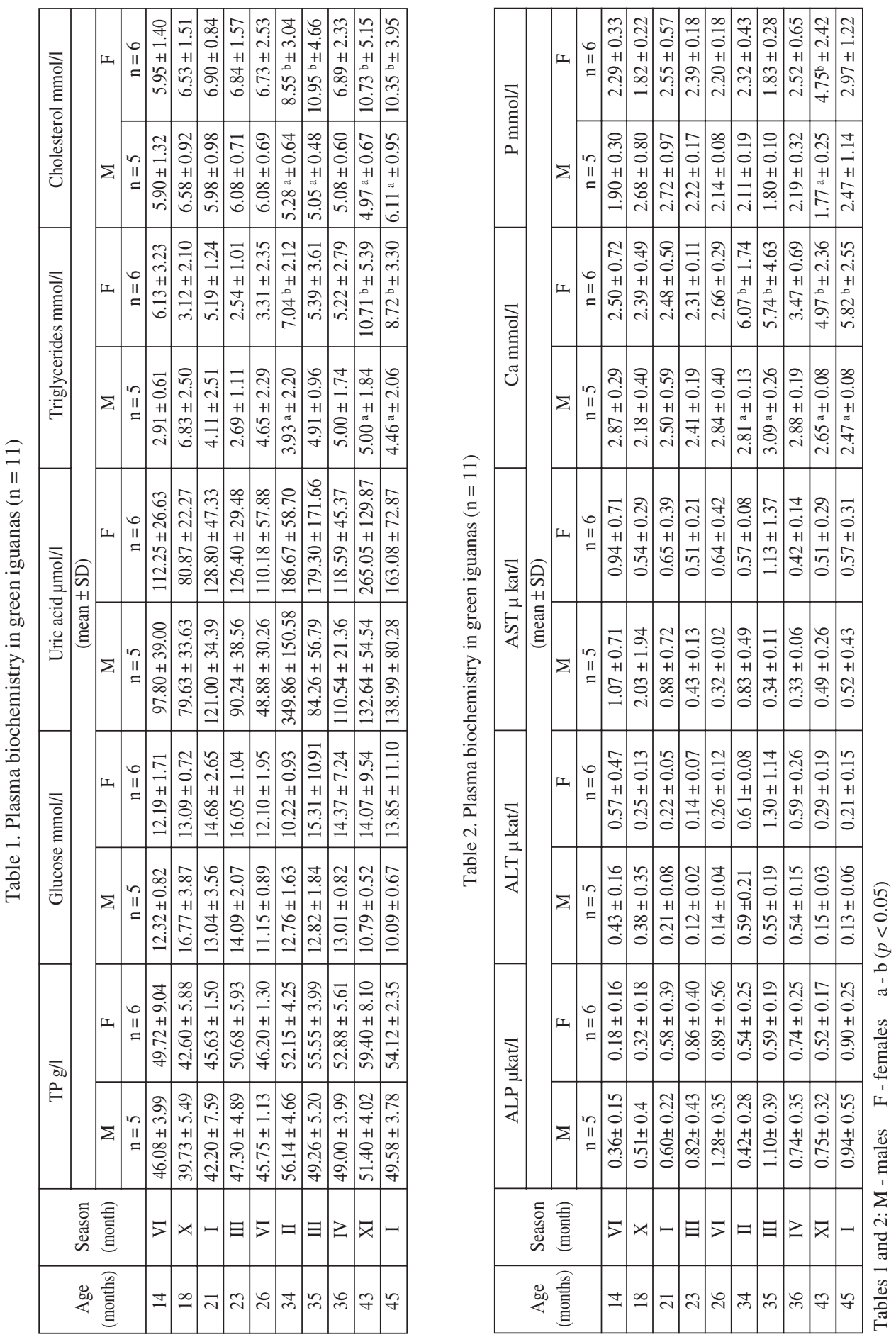
infertile eggs spontaneously $(11-32)$ whereas the other three females remained restful with distended bodies. Radiography revealed a typical picture for pre-ovulatory follicle stasis (POFS) - distended mass occupying almost the whole coelomic cavity. Ovariectomy was performed in each of females with POFS through a ventral midline approach under the inhalant anaesthesia with isoflurane (Bennet and Mader 1996; Divers 1996; 2000) at the end of 35 months.

Blood collection and plasma biochemistry

When the iguanas were 14 to 45 months old, blood samples were taken every 30 days or more days. Blood samples were collected from the ventral coccygeal vein, the animals were restrained manually, without sedation. Blood samples in tubes containing heparin (Heparin Leciva inj., Prague) were centrifuged and plasma biochemical assays were performed within 2 hours after collection by the use of automated analyzers. The concentration of total protein (TP), glucose, uric acid, alkaline phosphatase (ALP), alanine aminotransferase (ALT), aspartate aminotransferase (AST), cholesterol, triglycerides (TAG), phosphorus (P) was determined with a CobasMira analyzer (Roche); plasma concentrations of calcium $(\mathrm{Ca})$ were determined by the Atomspec analyzer (Hilger 1550).

\section{Statistical analyses}

The statistical assay analysis was performed using Stat Plus software (Stat Plus, version 1.01, 1990, VUVeL Brno, Czech Republic). To establish differences between individual sample-takings, the paired $t$-test was used, while differences between males and females were established using the classic $t$-test. For the results to be valid, selected data sets were subjected to the Box-Cox transformation prior to testing to obtain a normal basic distribution.

\section{Results}

Results of plasma biochemistry examinations of iguanas over the period of the trial are stated in Tables 1 and 2 . We revealed significantly $(p<0.05)$ higher concentrations of calcium, cholesterol and triglycerides in females than in males of iguanas within two periods of their reproductive seasons (months 34, 35, 43 and 45, February-March, NovemberJanuary).

The comparison of results obtained from females is described in detail in Table 3. Significantly higher concentrations of calcium and triglycerides were found in plasma samples of POFS females than in intact females after oviposition (month 35). During the next reproductive period (months 43 and 45) plasma concentrations of calcium, phosphorus, cholesterol and triglycerides were significantly higher in intact females than in OVE females.

\section{Discussion}

The natural habitat of the genus Iguana is variable. Green iguanas are found close to water in arid regions in the Neotropics (Rod da 2003). The subspecies Iguana iguana rhinolopha inhabits Central America, from Mexico to Costa Rica, i.e. a region with relatively constant temperature and light conditions but with dry and wet seasons (Burghardt and Rand 1982; Frye and Townsend 1993; Köhler 1993). In a previous study we have not recorded any seasonal changes of haematological values in our population of green iguanas. We believed that this resulted from the constant conditions under which the animals were kept throughout the year as well as due to the biological specifics of the reptile species (Pejřilová et al. 2004). Despite similar conditions, we have observed seasonal changes in plasma biochemistry in our group of iguanas, especially in females. This observation is in accordance with described correlations between season and sexual activity in green iguanas in their natural habitat (Alberts et al. 2003). Green iguanas exhibit highly seasonal and synchronized reproduction, which is manifested as copulations in December - January and oviposition in February - March (Rodda 2003).

Our previous trial showed no differences between males and females as to the haematological indices (Pejřilová et al. 2004). In the present study we reveal significant differences between males and females in plasma concentrations of calcium, cholesterol and triglycerides within a defined period of the year. We believe these changes may be the result 
of general physiological principles. The peripheral blood concentrations of calcium, cholesterol and triglycerides may correspond to the metabolic activity requirement, which is lower in adult males than in females during the breeding season. In birds it has been an established fact that calcium levels in peripheral blood of females peak during vitellogenesis (Jenkins 1994; Lumeij 1994). The domestic fowl has a considerable need for calcium during egg laying (Bentley 1998a). Similar physiological reason for the highest levels of calcium in peripheral blood of females green iguanas is therefore suggested and even supported with previous observations (Knotek et al. 2003; Knotková et al. 2004).

In fully gravid iguana the eggs fill most of the coelomic cavity and the feeding cesation is thought to be due to having insufficient space to support both metabolic breakdown of leaves in colon (distended caecum) and developing ova (van Marken Lichtenbelt et al. 1993; Rodda 2003). Based on our experience with breeding iguanas in captivity for many years we can add that even within the weeks of vitellogenesis female cease feeding (Knotková et al. 2004). Anorexia is regulary present in females suffering from pre-ovulatory follicular stasis (POFS) and post-ovulatory egg stasis (POES or POOS, Divers 1996, 2000; Not S chläpfer 2000; Knotková et al. 2004). It is not clear whether only insufficient space for ceacum activity is the reason for anorexia in females suffering from POFS or POES. Cholesterol and triglycerides could play an important role in the synthesis of steroid hormones as well as in energy metabolism and/or vitellogenesis (B entley 1998b).

In accordance with Jacobson (2003), we found elevated concentrations of calcium, phosphorus and cholesterol in the peripheral blood of adult females. However, unlike our trial, Jacobson did not specify in detail the exact reproductive status of females (he has characterized them as three early-gravid females and nine non-gravid female iguanas). Despite this, plasma concentrations of calcium, phosphorus and cholesterol of these Jacobson's early-gravid females correspond with values of vitellogenetic females in the present trial as well as with females with POFS (Knotková et al. 2004). In ovariectomized females we revealed a downward trend for examined parameters reaching the levels typical for males. During the following reproductive season intact females returned to the vitellogenic high concentrations of calcium, cholesterol and triglycerides whereas ovariectomized females did not. This is in accordance with data described previously (Clark 1967; Simkiss 1967; Bentley 1998a). The mechanism of hormonal control (Phillips et al. 1985, 1987; Pratt et al. 1994) for seasonal changes of calcium, cholesterol and triglyceride concentrations in blood of female green iguana remains to be examined in the future.

\section{Vliv reprodukční sezony na biochemické parametry krevní plazmy leguánů zelených}

Do sledování bylo zahrnuto jedenáct leguánů zelených (Iguana iguana rhinolopha, 5 samců a 6 samic, stáríi 10 měsíců) pocházejících ze společného vrhu z umělého odchovu. Leguáni byli chováni v experimentalních teráriích $(75 \mathrm{~cm} \times 85 \mathrm{~cm} \times 85 \mathrm{~cm})$ za konstantních podmínek světelného režimu, teploty a vlhkosti prostředí $\left(12 \mathrm{~h} / 12 \mathrm{~h}, 24-35^{\circ} \mathrm{C}, 60-80 \%\right)$. Celková kondice a zdravotní stav leguánů byly pravidelně kontrolovány. U tř́ samic došlo ve stáří 34 měsíců ke spontánnímu vykladení vajec, u tří samic byla z důvodu perzistence folikulů na ovariích (POFS) provedena na konci 35. měsíce ovariektomie. Koncentrace vápníku, cholesterolu a triglyceridů byly u samic signifikantně vyšší $(p<0.05)$ než u samců v období jejich reprodukční aktivity (únor - březen, listopad-leden). Výrazně vy̌̌ší koncentrace vápníku a triglyceridů byly zjištěny u samic s POFS než u zdravých samic po vykladení vajec. Koncentrace vápníku, fosforu, cholesterolu a triglyceridů byly výrazně vyšší u intaktních samic než u samic po ovariektomii. Předpokládaný mechanismus hormonální kontroly sezonních změn plazmatických koncentrací vápníku, cholesterolu a triglyceridů u samic leguána zeleného je nutno potvrdit. 


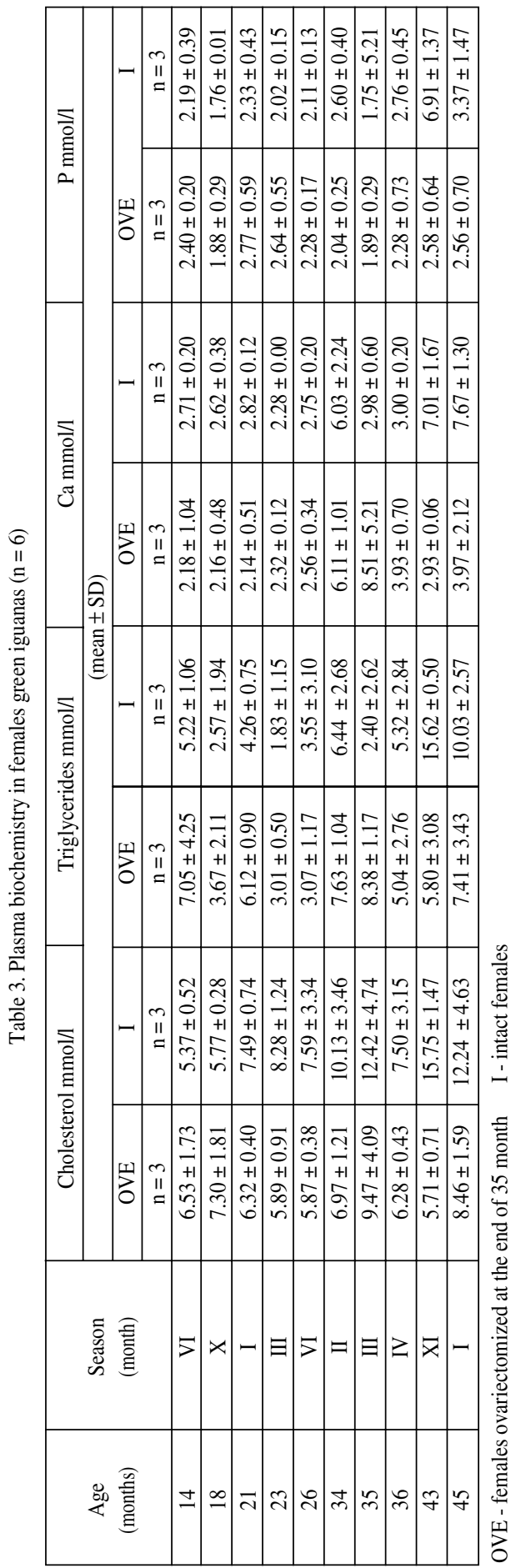

\section{Acknowledgements}

This project was partially supported by two research funds (grant MSMT 161700002 and IGA 34/2004).

\section{References}

ALBERTS AC, PRATT-HAWKES NC, PHILLIPS JA 2003: Ontogeny of Captive and Wild Iguanas: From Emergence to Mating. In: JACOBSON ER (ed) Biology, Husbandry, and Medicine of the Green Iguana. Krieger Publishing Comp. Malabar, pp. 2837

ANDERSON NL 1992: Husbandry and Clinical Evaluation of Iguana iguana. Comped Cont Educ Pract Vet 13: 1265-1269

BARTEN SL 1993: The medical care of iguanas and other common pet lizards. Vet Clin North Amer SAP 23: $1213-1249$

BARTEN SL 2002: Green Iguana Management and Husbandry. Suppl Compend Cont Educ Pract Vet 24: $13-22$

BENNETT RA, MADER DR 1996: Soft Tissue Surgery. In: MADER DR (ed) Reptile Medicine and Surgery. WB Saunders, Philadelphia, pp. 287-298.

BENTLEY PJ 1998a: Hormones and calcium metabolism. In: BENTLEY PJ (ed) Comparative Vertebrate Endocrinology. 3rd ed. Cambridge University Press Cambridge, pp. 269-301

BENTLEY PJ 1998b: Hormones and nutrition. In: BENTLEY PJ (ed) Comparative Vertebrate Endocrinology. 3rd ed. Cambridge University Press, Cambridge, pp. 223-268

BRUDER M 1998: Blutreferenzwerte bei Grünen Leguanen (Iguana iguana). Thesis, Univ München, $113 \mathrm{p}$.

BURGHARDT GM, RAND AS 1982: Iguanas of the World. Noyes Publ. Park Ridge, 472 p.

CAMPBELL TW 1996: Clinical pathology. In MADER DR (ed) Reptilie Medicine and Surgery. WB Saunders, Philadelphia, pp. 248-257

CLARK NB 1967: Influence of estrogens upon serum calcium, phosphate and protein concentrations of fresh-water turtles. Comp Biochem Physiol 20: 823834

DESSAUER MC 1970: Blood Chemistry of Reptiles: Physiological and Evolutionary Aspects. In: GANS C, PARSONS TS (eds.): Biology of the Reptilia, vol. 3 - Morphology C. Academic Press, London, pp. 172

DIVERS SJ, REDMAYNE G, AVES EK 1996: Haematological and biochemical values of 10 green iguanas (Iguana iguana). Vet Rec 138: 203-205

DIVERS SJ 1996: Medical and Surgical Treatment of Pre-ovulatory Ova Stasis and Post-ovulatory Egg Stasis in Oviparous Lizards. Proc Assoc Rept Amphib Vet 24-27 (8): 119-123

DIVERS SJ 2000: Reptilian renal and reproductive disease diagnosis. In: FUDGE, AM (ed.) Laboratory medicine: avian and exotic pets. WB Saunders, Philadelphia, pp. 217-219

FRYE FL, TOWNSEND W 1993: Iguanas. A guide to their biology and captive care. Krieger Publishing Comp, Malabar, 145 p. 
HARR KE, ALLEMAN AR, DENNIS PM, MAXWELL LK, LOCK BA, BENNET RA, JACOBSON ER 2001: Morphologic and cytochemical characteristics of blood cells and hematologic and plasma biochemical reference in green iguanas. J Am Vet Med Assoc 218: 915-921

JACOBSON ER 2003: Clinical Evaluation and Diagnostic Techniques. In: JACOBSON ER (Ed.) Biology, Husbandry, and Medicine of the Green Iguana. Krieger Publ. Com., Malabar, pp. 96-107

JENKINS JR 1994: Avian metabolic chemistries. Semin Avian Exotic Pet Med 3: 25-32

KNOTEK Z, HAUPTMAN K, KNOTKOVÁ Z, HÁJKOVÁ P, TICHÝ F 2002: Haemogram and plasma biochemistry in green iguanas with renal disease. Acta Vet Brno 71: 333-340

KNOTEK Z, KNOTKOVÁ Z, DOUBEK J, PEJŘILOVÁ S, HAUPTMAN K 2003: Plasma biochemistry in female green iguanas (Iguana iguana) with calcium metabolism disorders. Acta Vet Brno 72: 183-189

KNOTKOVÁZ, PEJŘILOVÁ S, KNOTEKZ 2004: Haemogram and plasma biochemistry in females green iguana with POOS versus POFS syndrome. Proc EAZWV Meeting, Ebeltoft, 19. 5. - 23. 5. 2004, pp. 287-289

KÖHLER G 1993: Der Grüne Leguan. G Köhler Verlag Hanau, 118 p.

KÖHLER G 1996: Krankheiten der Amphibien und Reptilien. Eugen Ulmer Verlag, 166 p.

KUBALEK S 2000: Untersuchungen zur Blutgerinnung beim Grünen Leguan (Iguana iguana). Thesis, Univ Hannover, $164 \mathrm{p}$.

NOT SCHLÄPFER I 2000: Follicular Stasis in the Green Iguana (Iguana Iguana). Proc Abstr EAZWV 3rd Scientific Meeting, 31. 5. - 4. 6. 2000, Paris, pp. 291-295

LUMEIJ JT 1994: Endocrinology. In: RITCHIE BW, HARRISON GJ, HARRISON LR (Eds) Avian Medicine, Principles and Application. Wingers Publ., Inc., Florida, pp. 582-606

PEJŘILOVÁ S, KNOTKOVÁ Z, KNOTEK Z, VRBAS J 2004: Age-related changes of the haematological profile in green iguana (Iguana iguana rhinolopha). Acta Vet Brno 73: 305-312

PHILLIPS JA, LASLEY BL, FRYE FL 1985: Gonadotropin-releasing hormone induces fertile matings in Iguana iguana during their refractory phase. Amer Zool 25: p. 134.

PHILLIPS JA, FRYE FL, BERCOVITZ A, CALLE P, MILLER R, RIVIER J, LASLEY BL 1987: Iguana iguana: A model species for studying the ontogeny of behavior/hormone interactions. J Exp Zool 241: 227-236

PRATT NC, PHILLIPS JA, ALBERTS AC, BOLDA KS 1994: Functional versus physiological puberty: an analysis of sexual bimaturism in the green iguana, Iguana iguana. Anim Behav 47: 1101-1114

REDROBE S, MacDONALD J 1999: Sample collection and clinical pathology of reptiles. Vet Clin North Amer EAP 2: 709-730

RODDA GH 2003: Biology and Reproduction in the Wild. In: JACOBSON ER (ed) Biology, Husbandry, and Medicine of the Green Iguana. Krieger Publ. Com., Malabar, pp. 1-27

SIMKISS K 1967: Calcium in Reproductive Physiology: A Comparative Study of Vertebrates. Chapman and Hall, London, pp. 214-220

van MARKEN LICHTENBELT WD, WESELINGH RA, VOGEL JT, ALBERTS KB 1993: Energy budgets in free-living green iguanas in a seasonal environment. Ecology 74: 1157-1172

WAGNER RA, WETZEL R 1999: Tissue and plasma enzyme activities in juvenile green iguanas. Amer J Vet Res 60: $201-203$

WALTON RM 2001: Establishing Reference Intervals. Health as a relative Concept. Semin Avian Exotic Pet Med 10: $66-71$ 